\title{
Obesity phenotypes: normal-weight individuals with metabolic disorders versus metabolically healthy obese
}

\author{
Corresponding author: \\ Paulina Cembrowska \\ Department of Laboratory Medicine \\ Nicolaus Copernicus University, \\ Collegium Medicum in Bydgoszcz \\ Skłodowskiej-Curie 9 St. \\ 85-094 Bydgoszcz, Poland \\ E-mail: paulina.cembrowska@wp.p
}

Medical Research Journal 2016;

Volume 1, Number 3, 95-99

10.5603/MRJ.2016.0016

Copyright (C) 2016 Via Medica

ISSN 2451-2591

\begin{abstract}
According to recent studies, adipose tissue secretes a large number of bioactive proteins, which affect the whole body metabolism. The amount of adipose tissue is the main factor that explains metabolic disorders; however, obesity is not necessarily the result of increased body weight. Interestingly, there is a subgroup of patients with normal weight and high-risk metabolic profile. Consequently, they are significantly more likely to have metabolic disorders or cardiovascular disease (CVD). Conversely, some individuals, called metabolically healthy obese ( $\mathrm{MHO}$ ), demonstrate a favourable metabolic profile despite having high BMI index and excessive adipose tissue.

The aim of this paper is to review recent studies about obesity phenotypes. Better understanding of differences between metabolically obese normal-weight (MONW) and $\mathrm{MHO}$ may improve the therapy and treatment of metabolic health in all obese patients. Equally importantly, it may lead to an increase in early detection of individuals with metabolic disorders, regardless of their body mass value or BMI.

Key words: adipose tissue, obesity phenotypes, metabolically healthy obese, visceral adipose tissue, metabolically obese normal-weight
\end{abstract}

Med Res J 2016; 1, 3: 95-99

\section{Introduction}

It is becoming increasingly difficult to ignore the fact that obesity is the epidemic of our century and one of the major public health concerns. This medical condition contributes to increased mortality. Modern lifestyle leads to the development of metabolic disorders and ectopic accumulation of adipose tissue, which are closely associated with the growth in the prevalence of type 2 diabetes, cardiovascular diseases, non-alcoholic fatty liver disease, dyslipidaemia, and hypertension [1-5]. Furthermore, treatment of obesity and obesity-related complications generates high costs. Thus, the aim of medicine nowadays is to identify those who are at risk of developing obesity and metabolic disorders, and to try to prevent secondary clinical complications [6-8].

At present it appears to be difficult to prepare consistent guidelines for obesity treatment. According to many studies, obesity is not only connected with increased body weight and value of BMI [5, 9]. The interesting finding is that there are significant differences in the metabolic profiles between people assigned to the same categories of BMI. It shows that the major problems are composition and distribution of body fat instead of the amount of adipose tissue [5, 10-12]. Therefore, it became essential to distinguish the particular type of accumulated fat mass. Visceral fat has been considered as an active endocrine organ that may contribute to the development of many metabolic disorders. An excess of this type of fat is more disquieting [5, 10, 13, 14]. Subcutaneous fat does not have as important an impact on metabolic parameters in humans as visceral fat. However, adipose tissue accumulated in this depot has a large volume and secretory properties that affect the balance of our body $[12,13,14]$.

The purpose of this paper is to review the most recent information about obesity phenotypes. Due to the fact that an excess of visceral fat may not significantly affect the BMI and waist circumference measurement, there is a subgroup of obesity which is characterized by normal weight and an increase in the possibility of developing type 2 diabetes, dyslipidaemia, and liver fat $[5,9,15]$. On the other hand, not all obese individuals demonstrate adverse metabolic effects, and their cardio-metabolic risk may be even lower than for the above-mentioned group [6, 16, 17]. 


\section{Visceral and subcutaneous adipose tissue}

The term "obesity" is generally used to describe the excess accumulation of body fat, frequently measured by BMI or waist circumference value $[9,14]$. However, many studies have established that the BMI formula is only a mathematical estimate, useful in population studies. According to recent investigations, it is necessary to assess the composition and distribution of body fat, rather than to simply measure the body weight. Therefore, there has been increasing interest in the role of adipose tissue in lipid and glucose metabolism. Due to the fact that these tissues secrete a large number of bioactive proteins and pro-inflammatory cytokines, adipocyte metabolism appears to be a major cause of the development of metabolic disorders [7, 9, 14, 18]. Thus, it is crucial to evaluate the regional distribution of fat and ectopic fat depots. The content of visceral and subcutaneous adipose tissue seems to be the main issue to explain the metabolic abnormalities in individuals representing various obesity phenotypes, mainly in the context of secretion of different adipokines and other bioactive substances [14, 19].

Therefore, it seems that there is a strong correlation between an excess of adipose tissue in the central part of the body and the occurrence of metabolic disorders. Generally, the risk of metabolic syndrome is lower when body fat is stored in the peripheral part of the body [13, 19-21]. Visceral adipose tissue (VAT) is stored in the abdominal cavity and surrounds internal organs, while subcutaneous adipose tissue is mainly located peripherally (Fig. 1) [13, 19].

According to Bays et al., a positive energy balance leads to an excess of free fatty acids, which are accumulated in subcutaneous adipose tissue. However, an imbalance of energy may also lead to fat accumulation in ectopic depots as visceral adipose tissue, surrounding the heart and vasculature [19, 22].

It is important to distinguish visceral and subcutaneous adipose tissue in connection with the expression of different adipokines. Visceral adiposity is associated with an adverse cardiometabolic profile, including inflammation, insulin resistance, and myocardial dysfunction. Due to the fact that VAT surrounds abdominal organs and is located near the portal vein, substances secreted by this tissue are transported throughout the organism $[19,20]$. The excess of visceral fat supports pathological vascular changes by secretion of pro-inflammatory and pro-atherosclerotic mediators, such as interleukin 6 (IL-6), plasminogen activator inhibitor-1 (PAl-1), and glucocorticoids, which account for the development of cardiovascular diseases such as coronary artery disease and cardiac dysfunction [19-21, 23]. It has also been observed that increased concentrations of C-reactive protein (CRP), tumour necrosis factor

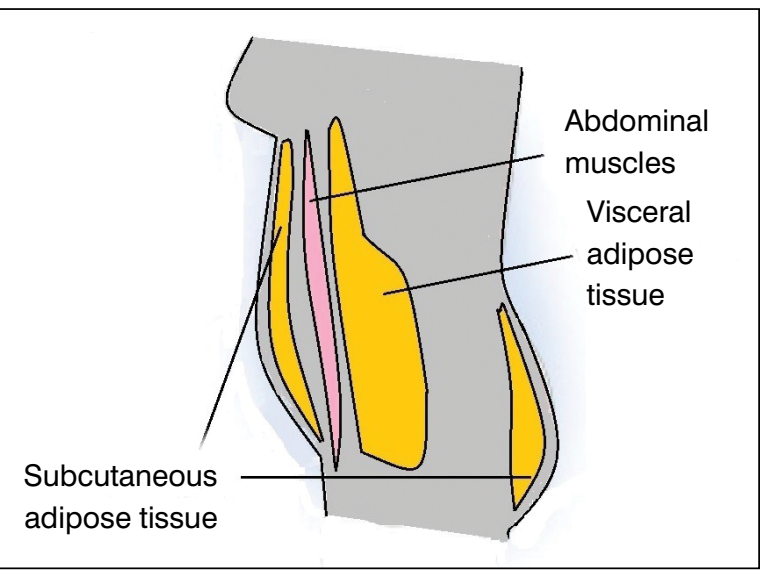

Figure 1. Visceral and subcutaneous adipose tissue localisation [24]

(TNF- $\alpha$ ), and interleukin 18 (II-18) lead to a state of chronic low-grade inflammation [19, 21]. Greater insulin resistance has been observed in patients with visceral fat obesity. Jung et al. point out that increasing secretion of monocyte chemotactic protein (MCP-1), TNF- $\alpha$, interleukin 1 (II-1), II-6, and interleukin 8 (II-8) contributes to development of type 2 diabetes. Matsuzawa et al. have also reported that VAT reduction contributes to decreasing blood pressure [10, 23].

The main role of subcutaneous adipose tissue (SAT) is to accumulate an excess of energy during positive caloric balance, which may be metabolically 'protective' if proliferation and differentiation of fat cells proceed properly. In contrast to visceral fat, it secretes adiponectin, which has a protective and anti-inflammatory role [19, 21]. In many studies it has been suggested that the excess of SAT has a stronger correlation with insulin sensitivity than VAT [13]. Furthermore, Britton et al., in their review, draw our attention to the ability of subcutaneous fat to promote angiogenesis and a greater capillary network in comparison to visceral fat, which leads to a higher blood flow [22].

In summary, researchers have shown recently that adipose tissue is not only for energy storage, but also it affects the whole body metabolism through a large number of bioactive proteins. Due to differences between subcutaneous and visceral adipose tissue, it is crucial to evaluate the composition and distribution of body fat instead of the amount of adipose tissue. The screening of body fat distribution may become a useful tool in the prevention of obesity-related diseases, and evaluation and proper classification of the obese $[13,14,20]$.

\section{Obesity phenotypes}

In the 1980s Ruderman et al. observed and first described some non-obese individuals with metabolic 
Table 1. Obesity phenotypes

\begin{tabular}{|c|c|c|c|c|}
\hline & $\begin{array}{l}\text { Normal-weight obese } \\
\text { (NWO) }\end{array}$ & $\begin{array}{c}\text { Metabolically obese } \\
\text { normal-weight (MONW) }\end{array}$ & $\begin{array}{c}\text { Metabolically healthy } \\
\text { obese (MHO) }\end{array}$ & $\begin{array}{c}\text { Metabolically unhealthy } \\
\text { obese (MUO) }\end{array}$ \\
\hline \multicolumn{5}{|c|}{ 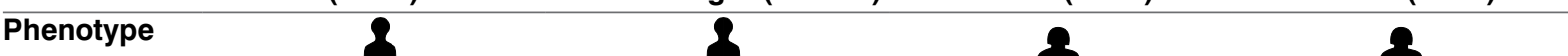 } \\
\hline BMI $\left[\mathrm{kg} / \mathrm{m}^{2}\right]$ & $18.5-25$ & $18.5-25$ & $>30$ & $>30$ \\
\hline Fat mass (\%) & $M>23.5, W>29.2$ & $>30$ & $>30$ & $>30$ \\
\hline Fat distribution & $\begin{array}{l}\text { Low lean body mass, } \\
\text { higher than norm total body } \\
\text { fat }\end{array}$ & $\begin{array}{l}\text { High content of visceral } \\
\text { adipose tissue, low lean } \\
\text { body mass and ectopic fat }\end{array}$ & $\begin{array}{l}\text { Less visceral and ectopic } \\
\text { fat than MUO }\end{array}$ & $\begin{array}{l}\text { Fat cumulated mostly in } \\
\text { visceral adipose tissue, } \\
\text { ectopic fat }\end{array}$ \\
\hline $\begin{array}{l}\text { Glucose } \\
\text { metabolism }\end{array}$ & Higher fasting glucose level & Low insulin sensitivity & Proper sensitivity of insulin & Insulin resistant, diabetes \\
\hline Lipid profile & $\begin{array}{l}\text { Improper lipid } \\
\text { concentrations }\end{array}$ & $\begin{array}{l}\text { Concentrations of hdl- } \\
\text { cholesterol low and } \\
\text { triglycerides high }\end{array}$ & Proper & $\begin{array}{l}\text { Improper lipid } \\
\text { concentrations }\end{array}$ \\
\hline Inflammation & $\begin{array}{c}\text { Early inflammatory } \\
\text { status, higher values of } \\
\text { proinflammatory cytokines }\end{array}$ & $\begin{array}{l}\text { Early inflammatory status, } \\
\text { the increased levels of } \\
\text { inflammation biomarkers }\end{array}$ & Low degree & $\begin{array}{l}\text { Permanent high } \\
\text { inflammatory status }\end{array}$ \\
\hline $\begin{array}{l}\text { Clinical } \\
\text { significance }\end{array}$ & $\begin{array}{l}\text { Higher risk of metabolic } \\
\text { syndrome, hypertension } \\
\text { (M), CVD (W) }\end{array}$ & Metabolic syndrome, CVD & $\begin{array}{l}\text { Display obesity-related } \\
\text { complications }\end{array}$ & $\begin{array}{l}\text { Display obesity-related } \\
\text { complications, metabolic } \\
\text { syndrome, CVD }\end{array}$ \\
\hline
\end{tabular}

$\mathrm{BMI}$ - body mass index; M — man; W - woman; CVD - cardiovascular disease

abnormalities and obese people with a proper metabolic profile. Recent research has demonstrated that individuals classified on the basis of body weight or BMI do not always exhibit the same risk of cardiovascular diseases (CVD) and metabolic syndrome. According to Lorenzo et al., currently there are four phenotypes of obesity [5]:

- normal-weight obese (NWO);

_ metabolically obese normal-weight (MONW);

- metabolically healthy obese (MHO);

- metabolically unhealthy obese (MUO).

However, there are still no strictly defined diagnostic criteria for phenotypes of obesity. Furthermore, researchers are mostly focused on MONW and MHO groups, as the potential incorrect classification of these individuals - MONW as healthy and MHO as ordinary obese. Individuals belonging to NWO and MONW both represent a state of increased body fat content with normal weight; nevertheless, there are minor differences between their representatives [5, 25]. The table below illustrates the comparison of obesity phenotypes according to current literature (Tab. 1) [5, 25-27].

\section{Normal-weight obese (NWO)}

Individuals belonging to this phenotype have normal BMI (18.5-25 kg/m²); however, their body fat percentage is above the norm (men $-23.5 \%$ and women $-29.2 \%$ ), which contributes to a higher risk of metabolic abnormalities [5, 25]. According to Lorenzo et al., NWO individuals may demonstrate higher fasting glucose levels, hypertension, disorders in lipid profiles, early inflammatory status, and higher oxidative stress in comparison to healthy normal-weight individuals [5]. However, NWO patients do not develop all of the factors that are needed for recognition of metabolic syndrome in contrast to metabolically obese normal-weight individuals [5].

Many studies have shown that NWO individuals have elevated plasma concentrations of pro-inflammatory cytokines in comparison to metabolically healthy normal-weight people. Increased concentrations of TNF- $\alpha$, II-8, and IL-6 have been observed in this group. These data suggest the occurrence of the early inflammatory response, which may be due to the increased content of fat mass [25]. Renzo et al. demonstrated that NWO patients have a higher level of oxidative stress markers, compared with the obese. The oxidative stress may be closely related to vascular dysfunction and the development of CVD [25, 27-29].

\section{Metabolically obese normal-weight (MONW)}

Representatives of this subgroup possess normal weight (BMI between 18.5 and $25 \mathrm{~kg} / \mathrm{m}^{2}$ ); however, they have a high content of visceral adipose tissue and fat mass, as well as low lean body mass and ectopic fat distribution [21, 25]. According to Thomas et al., these individuals demonstrate a higher ratio of visceral 
and subcutaneous abdominal adipose tissue [21]. According to Shea et al., individuals with normal weight belonging to this phenotype have been associated with an increased waist circumference and body fat [25, 30].

MONW is a group with a higher risk of developing metabolic syndrome, which is caused by the occurrence of low insulin sensitivity, low HDL-cholesterol, and high triglycerides concentrations. Moreover, they exhibited increased levels of inflammatory biomarkers and a higher risk of the occurrence of diabetes and cardiovascular disease. In fact, MONW individuals represent metabolic abnormalities typical of obesity [14, 31].

It seems to be difficult to determine the prevalence of MONW, due to the lack of a standardised definition of this phenotype. Some researchers evaluate that $23.5 \%$ of normal-weight adults represent the metabolically obese normal-weight subgroup, when metabolic syndrome criteria are used. However other data suggest that this phenotype prevalence is $3-28 \%$, depending on the used definition of metabolic risk [26, 32, 33]. Regarding race, there have been distinctions in prevalence of MONW phenotype - some studies have shown that Asians are more likely to be MONW than typically obese. According to Mathew et al., Chinese people have a higher risk of intra-abdominal obesity and ectopic accumulation of fat, even if they tend to be lean [32]

Generally, it is recommended that MONW individuals modify their lifestyle by a suitable diet and exercise program supported by the appropriate therapy for metabolic disorders [34].

\section{Metabolically healthy obese (MHO)}

The metabolically healthy obese subgroup was first featured in 1982 and represents $10-30 \%$ of the whole group of obese; however, until now there has been no standardised definition of this phenotype [6, 8, 35]. According to BMI classification, individuals belonging to this subgroup are obese, with BMI over $30 \mathrm{~kg} / \mathrm{m}^{2}$, but they do not have metabolic abnormalities. Although they have the excess of adipose tissue, they possess less visceral and ectopic fat with low hepatic steatosis. Consequently, their metabolic profiles are favourable: no hypertension, high insulin sensitivity, and correct lipid and hormonal profile. However, MHO individuals display other obesity-related complications: chronic pain, sleep problems, pulmonary disease, articulation and postural problems, etc. [1, 6, 7, 36]. Moreover, Samocha-Bonet et al. suggest that $30 \%$ of $\mathrm{MHO}$ people may be transitioned to the metabolically unhealthy obese group, while others propose as many as $50 \%$ [8]. Thus, longitudinal studies seem to be crucial to evaluate the possibility of developing metabolic complications typical of obesity [32].
Surprisingly, $\mathrm{MHO}$ individuals frequently represent a high fitness level, which is associated with less visceral and intrahepatic fat content [6]. This may explain the fact that the lifestyle and diet change have no effect on BMI modifications in these subjects [32, 37]. Other studies suggest that the occurrence of the MHO phenotype is not related to physical activity, alcohol consumption, or diet. However, some researches point out smoking and lower education levels as potential risk factors [32, 38].

According to different data, $\mathrm{MHO}$ phenotype is associated with lower plasma concentrations of TNF- $\alpha$, IL-6, and CRP, which is related to a low degree of inflammation. It can also display a favourable lipid profile - high concentration of HDL cholesterol, high LDL level, and low triglycerides [32, 39].

Messier et al., in their study, showed lower concentrations of hepatic enzymes (alkaline phosphatase, alanine aminotransferase, aspartate aminotransferase, $\gamma$-glutamyl transferase) in MHO plasma in comparison with the obese with risk of metabolic syndrome [40].

\section{Metabolically unhealthy obese (MUO)}

The metabolically unhealthy obese are characterised by $\mathrm{BMI}$ over $30 \mathrm{~kg} / \mathrm{m}^{2}$ and body fat percentage over $30 \%$. In addition, excess fat mass is cumulated mostly in visceral adipose tissue, which leads to the development of metabolic syndrome, diabetes, cardiovascular disease, and increased mortality. There are defined diagnostic criteria and guidelines for these patients [5]. Individuals representing MUO phenotype are simply recognised by the physician or they report themselves for medical support.

\section{Conclusions}

The crucial finding of the presented review is the fact that individuals belonging to all four obesity phenotypes are at risk of developing obesity-related diseases; however, NWO and MONW individuals are mostly unaware that they are in the risk group. Frequently screening tests are based on anthropometric measures, which is associated with misclassification of these individuals.

The second significant finding to emerge from this review is that individuals representing both phenotypes — metabolically healthy obese and metabolically obese normal-weight - have the same risk of disturbances related to obesity, and they require medical care. Although $\mathrm{MHO}$ individuals do not demonstrate metabolic disorders, they also need medical attention and periodic weight management because of obesity-related complications.

Therefore, it seems that medical education may be crucial in the prevention of development of obesity and 
metabolic disorders. There is a definite need for new guidelines for obesity treatment dependent on phenotype, which allows an estimation of the inflammatory and metabolic profile of the patient, independently of BMl and body size.

\section{References}

1. Roberson LL, Aneni EC, Maziak W et al. Beyond BMI: The "Metabolically healthy obese" phenotype \& its association with clinical/subclinical cardiovascular disease and all-cause mortality — a systematic review. BMC Public Health 2014; 14: 14

2. Rodríguez-Hernández H, Simental-Mendía LE, Rodríguez-Ramírez G, Reyes-Romero MA. Obesity and inflammation: epidemiology, risk factors, and markers of inflammation. International Journal of Endocrinology 2013; Article ID 678159.

3. Alfadda AA. Circulating adipokines in healthy versus unhealthy overweight and obese subjects International. Journal of Endocrinology 2014; Article ID 170434

4. Giordano A, Smorlesi A, Frontini A, Barbatelli G, Cinti S. White, brown and pink adipocytes: the extraordinary plasticity of the adipose organ. European Journal of Endocrinology 2014; 170: R159-R171.

5. De Lorenzo A, Soldati L, Sarlo F, Calvani M, Di Lorenzo N, Di Renzo L. New obesity classification criteria as a tool for bariatric surgery indication. World J Gastroenterol 2016; 22: 681-703.

6. Blüher M. Are metabolically healthy obese individuals really healthy? European Journal of Endocrinology 2014; 171: R209-R219.

7. Phillips $\mathrm{CM}$, Dillon C, Harrington JM et al. Defining metabolically healthy obesity: role of dietary and lifestyle factors. PLoS One 2013; 8/10: e76188.

8. Samocha-Bonet D, Dixit VD, Kahn CR et al. Metabolically healthy and unhealthy obese - the 2013 Stock Conference report. Obesity Reviews 2014; 15: 697-708.

9. Blundell JE, Dulloo AG, Salvador J, Frühbeck G. Beyond BMI - phenotyping the obesities. Obese Facts 2014; 7: 322-328.

10. Jung U-J, Choi M-S. Obesity and Its metabolic complications: the role of adipokines and the relationship between obesity, inflammation, insulin resistance, dyslipidemia and nonalcoholic fatty liver disease. Int J Mol Sci 2014; 15: 6184-6223.

11. Shah RV, Murthy VL, Abbasi SA et al. Visceral adiposity and the risk of metabolic syndrome across body mass index. JACC Cardiovasc Imaging 2014; 7: 1221-1235.

12. Bener A, Yousafzai MT, Darwish S, Al-Hamaq AO, Nasralla EA, Abdul-Ghani M. Obesity index that better predict metabolic syndrome: body mass index, waist circumference, waist hip ratio, or waist height ratio. Journal of Obesity 2013; Article ID 269038.

13. Patel P, Abate N. Role of subcutaneous adipose tissue in the pathogenesis of insulin resistance. Journal of Obesity 2013; Article ID 489187.

14. Huffman DM, Barzilai N. Role of visceral adipose tissue in aging Biochim Biophys Acta 2009; 1790: 1117-1123.

15. Lee $\mathrm{S}-\mathrm{H}$, Han $\mathrm{K}$, Yang $\mathrm{HK}$ et al. A novel criterion for identifying metabolically obese but normal weight individuals using the product of triglycerides and glucose. Nutrition \& Diabetes 2015; 5: e149.

16. Denisa GV, Obinb MS. 'Metabolically healthy obesity': Origins and implications. Mol Aspects Med 2013; 34: 59-70.

17. Shaharyar S, Roberson LL, Jamal O et al. Obesity and metabolic phenotypes (metabolically healthy and unhealthy variants) are significantly associated with prevalence of elevated c-reactive protein and hepatic steatosis in a large healthy Brazilian population. Journal of Obesity 2015; Article ID 178526.

18. Dua T, Zhanga J, Yuana $G$ et al. Nontraditional risk factors for cardiovascular disease and visceral adiposity index among different body size phenotypes. Nutr Metab Cardiovasc Dis 2015; 25: 100-107.
19. Bays H. Central obesity as a clinical marker of adiposopathy; increased visceral adiposity as a surrogate marker for global fat dysfunction. Curr Opin Endocrinol Diabetes Obes 2014; 21: 345-351.

20. Tchernof A, Després J-P. Pathophysiology of human visceral obesity: an update. Physiol Rev 2013; 93: 359-404, doi:10.1152.

21. Wajchenberg BL, Nery M, Cunha MR, Rossi da Silva ME. Adipose tissue at the crossroads in the development of the metabolic syndrome, inflammation and atherosclerosis. Arq Bras Endocrinol Metab 2009: 53: 145-150.

22. Britton KA, Fox CS. Ectopic fat depots and cardiovascular disease. Circulation 2011; 124: e837-e841.

23. Matsuzawa Y. Establishment of a concept of visceral fat syndrome and discovery of adiponectin. Proc Jpn Acad (Ser. B) 2010; 86: 131-140.

24. Ebbert JO, Jensen MD. Fat depots, free fatty acids, and dyslipidemia Nutrients 2013; 5: 498-508.

25. De Lorenzo A, Del Gobbo V, Premrov MG, Bigioni M, Galvano F, Di Renzo L. Normal-weight obese syndrome: early inflammation? Am J Clin Nutr 2007; 85: 40-45.

26. Milewicz A. Fenotypy otyłości a skład masy ciała i profil metaboliczny. Endokrynologia, Otyłość i Zaburzenia Przemiany Materii 2005; 1 : $15-19$.

27. Di Renzo L, Galvano F, Orlandi $\mathrm{C}$ et al. oxidative stress in normal-weight obese syndrome. Obesity 2010; 18: 2125-2130.

28. Fitzgibbons TP, Czech MP. Epicardial and perivascular adipose tissues and their influence on cardiovascular disease: basic mechanisms and clinical associations. J Am Heart Assoc 2014; 3: e000582.

29. Mittendorfer B. Origins of metabolic complications in obesity: adipose tissue and free fatty acid trafficking. Curr Opin Clin Nutr Metab Care 2011; 14: 535-541.

30. Shea JL, King MT, Yi Y, Gulliver W, Sun G. Body fat percentage is associated with cardiometabolic dysregulation in BMI-defined normal weight subjects. Nutr Metab Cardiovasc Dis 2012; 22: 741-747.

31. Nowak M, Grzywa M. Metaboliczna otyłość z prawidłową masą ciała i otyłość z prawidłowymi wskaźnikami metabolicznymi a ryzyko metaboliczno-naczyniowe. Prz Med Uniw Rzesz Inst Leków 2015; 13: 270-278

32. Mathew H, Farr OM, Mantzoros CS. Metabolic health and weight: Understanding metabolically unhealthy normal weight or metabolically healthy obese patients. Metabolism 2016; 65: 73-80.

33. Pajunen P, Kotronen A, Korpi-Hyövälti E et al. Metabolically healthy and unhealthy obesity phenotypes in the general population: the FIN-D2D Survey BMC Public Health 2011; 11: 754.

34. Lee TH, Jeon WS, Han KJ et al. Comparison of serum adipocytokine levels according to metabolic health and obesity status. Endocrinol Metab 2015; 30: 185-194.

35. Seo MH, Rhee E-J. Metabolic and Cardiovascular Implications of a Metabolically Healthy Obesity Phenotype. Endocrinology and Metabolism 2014; 29: 427-434.

36. Eckel N, Mühlenbrucha K, Meidtner K, Boeing H, Stefanb N, Schulze MB. Characterization of metabolically unhealthy normal-weight individuals: Risk factors and their associations with type 2 diabetes. Metabolism Clinical and Experimental 2015; 64: 862-871.

37. Santos Gondim O, Nunes de Camargo VT, Gutierrez FA et al. Benefits of regular exercise on inflammatory and cardiovascular risk markers in normal weight, overweight and obese adults. PLoS One 2015; 10 : e0140596.

38. Camhi SM, Crouter SE, Hayman LL, Must A, Lichtenstein AH. Lifestyle behaviors in metabolically healthy and unhealthy overweight and obese women: a preliminary study. PLoS One 2015; 10: e0138548.

39. Berezina A, Belyaeva O, Berkovich O et al. Prevalence, Risk factors, and genetic traits in metabolically healthy and unhealthy obese individuals. BioMed Research International 2015; Article ID 548734.

40. Messiera V, Karelisc AD, Robillardc M-Ė, Bellefeuillec P, Brochud M, Lavoief J-M, Rabasa-Lhoreta R. Metabolically healthy but obese individuals: relationship with hepatic enzymes. Metabolism Clinical and Experimental 2010; 59: 20-24. 